\title{
Research Paper: \\ Assessing Anti-malaria Effect of Naja Naja Oxiana Snake Venom by Real-time Polymerase Chain Reaction Method
}

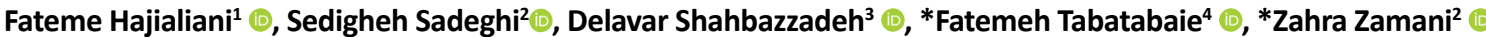

1. Department of Parasitology and Mycology, School of Medicine, International Campus, Iran University of Medical Sciences, Tehran, Iran

2. Department of Biochemistry, Pasteur Institute of Iran, Tehran, Iran.

3. Department of Medical Biotechnology, Biotechnology Research Center, Pasteur Institute of Iran, Tehran, Iran.

4. Department of Parasitology and Mycology, School of Medicine, Iran University of Medical Sciences, Tehran, Iran.

\begin{tabular}{|c|c|}
\hline $\begin{array}{l}\text { Use your device to scan } \\
\text { and read the article online }\end{array}$ & Cltation: Hajialiani F, Sadeghi S, Shahbazzadeh D, Tabatabaie F, Zamani Z. [Evaluation of Anti-plasmodium Effect Iranian \\
\hline aptip: & $\begin{array}{l}\text { Snake Venom by Real-time PCR (Persian)]. Complementary Medicine Journal. 2021; 11(1):68-81. https://doi.org/10.32598/ } \\
\text { cmja.11.1.1049.1 }\end{array}$ \\
\hline 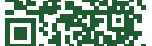 & dol'https://doi.org/10.32598/cmja.11.1.1049.1 \\
\hline
\end{tabular}

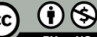

Article Info:

Received: 03 Jan 2021

Accepted: 28 Feb 2021

Available Online: 01 Apr 2021

Keywords:

Plasmodium

falciparum, Inhibi-

tory concentration

50, Snake venom,

Malaria, Real-time

Polymerase Chain

Reaction (PCR)

\section{A B STRACT}

Objective Malaria is one of the most important parasitic diseases and one of the important health issues especially in tropical and subtropical countries. The importance of this disease is due to its high prevalence and mortality, as well as drug resistance and side effects of common drugs used for its treatment. Snake venom is a complex mixture of active pharmaceutical ingredients. The present study aims to investigate the anti-Plasmodium falciparum activity of the purified fractions isolated from the venom of Iranian cobra snake (Naja Naja Oxiana) by real-time Polymerase Chain Reaction (PCR) method.

The importance of this disease is due to its high prevalence, significant mortality, as well as drug resistance and, side effects of current drugs in treatment. Venom is a complex mixture of active pharmaceutical ingredients. The purpose of this study was to investigate the anti-Plasmodium falciparum activity of the purified fraction of Iranian cobra snake venom by Real -time PCR.

Methods After preparation and purification of lyophilized venom for determining the parasitic load, different fractions obtained from the venom of Naja Naja Oxiana put in different plates adjacent to Plasmodium falciparum (3D7) strain in the ring stage. The degree of parasitemia was determined by real-time PCR. Finally, the effective fraction with anti-malaria properties was identified.

Results The active fraction with a half maximal inhibitory concentration of $0.026 \mu \mathrm{g} / \mathrm{mL}$ was the most effective fraction on Plasmodium falciparum in vitro $(P<0.001)$.

Conclusion The active fraction of Naja Naja Oxiana venom at the mentioned concentration has antimalaria effect. This results can motivate the continuation of further research in this field.

\section{Extended Abstract}

\section{Introduction}

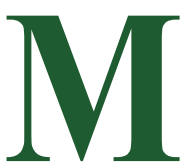

alaria mortality has dropped worldwide due to the worldwide malaria eradication program and the use of artemisininbased combination therapy and some medications. However, the prevalence of Plasmodium falciparum strains that are resistant to standard drugs such as chloroquine has increased in many parts of the world. In recent years, one of the main causes of death from malaria has been reported to be increased drug resistance; hence, scientists are looking for new drugs to control the disease.
* Corresponding Author:

Fateme Tabatabaie, PhD.

Address: Department of Parasitology and Mycology, School of Medicine, Iran University of Medical Sciences, Tehran, Iran.

Tel: +98 (21) 86703220

E-mail: tabatabaie59@gmail.com
Zahra Zamani, PhD.

Address: Department of Biochemistry, Pasteur Institute of Iran, Tehran, Iran.

Tel: +98 (21) 86703220

E-mail: tabatabaie59@gmail.com 


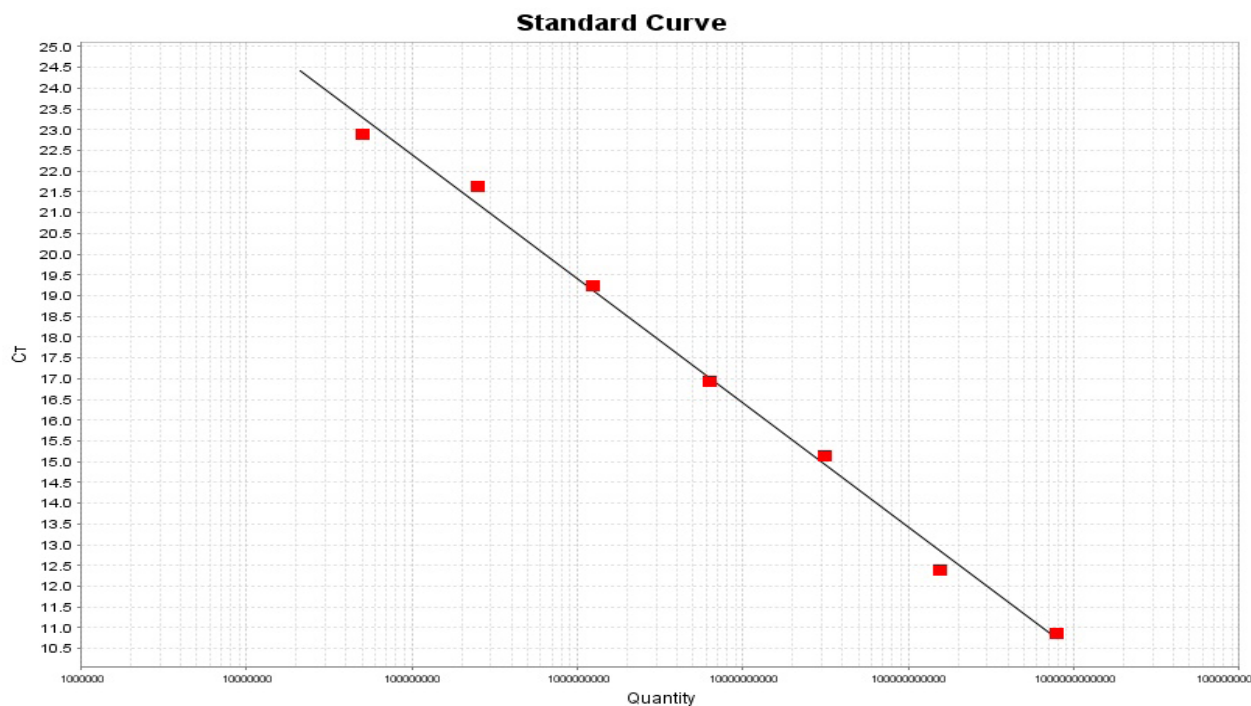

Figure 1. Standard curve of 18s rRNA gene synthesized in vitro

With the advancement of medical science and related sciences, many studies have been conducted on the chemical properties of various toxins. Today, snake venom can be used to prepare various drugs, serums and vaccines. In recent years, researchers have been investigated the properties of snake venoms for increasing the drug resistance to Plasmodium falciparum. Their results have shown that the venom of Bothrops asper snake and South American rattlesnake have cell penetrating, antifungal and antiparasitic properties. Iranian cobra (Naja Naja Oxiana) is a snake from the family Elapidae that is found in large areas in northeastern Iran. The aim of this study was to investigate the anti-malaria effect (in the ring stage) of the active fraction isolated from Iranian cobra venom by determining the parasitic load using Real-time PCR.

\section{Materials and Methods}

After determining the effective dose of active fraction, the materials were first mixed slowly and on ice with a sampler in two vials of $0.2 \mathrm{cc}$. For all primers used in the Real-time PCR, 10\% stocks were prepared from the initial

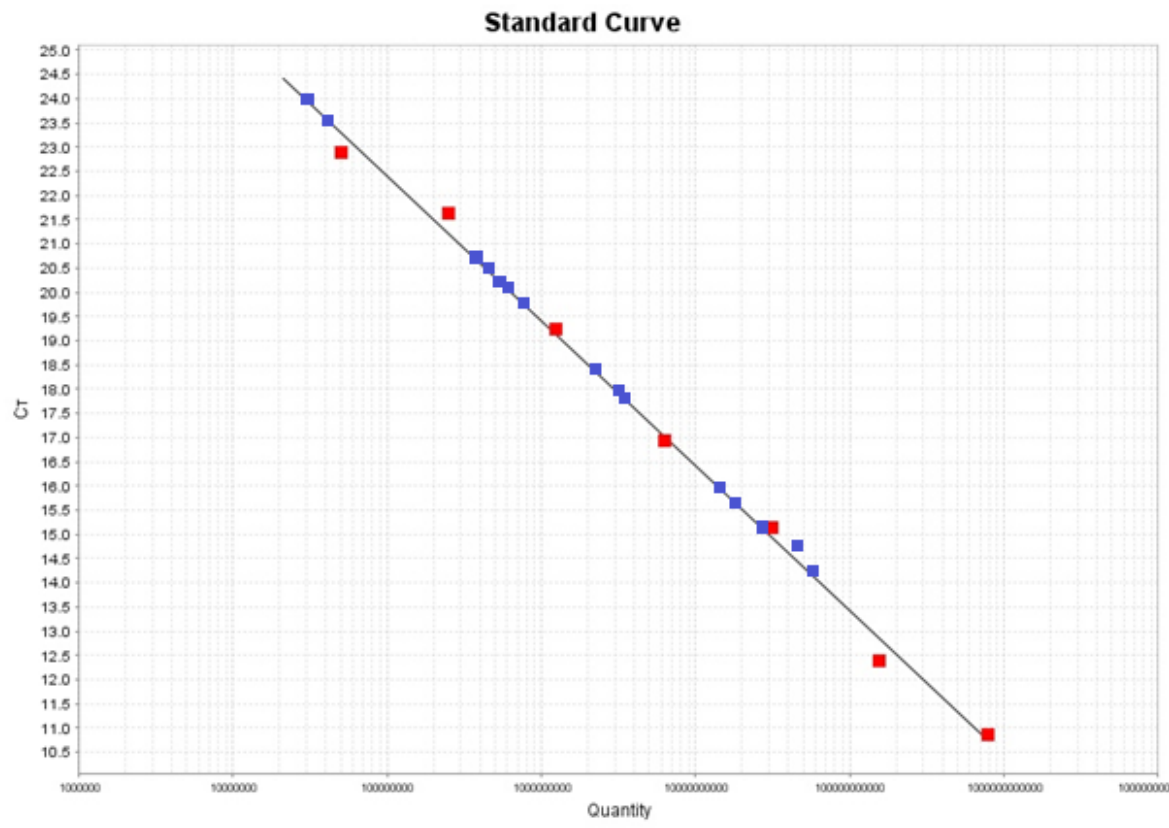

数 Complementary Medicine Journal

Figure 2. Standard curve of synthesized 18s rRNA gene and samples extracted from Plasmodium falciparum in culture medium adjacent to active fraction for IC50 testing in vitro 


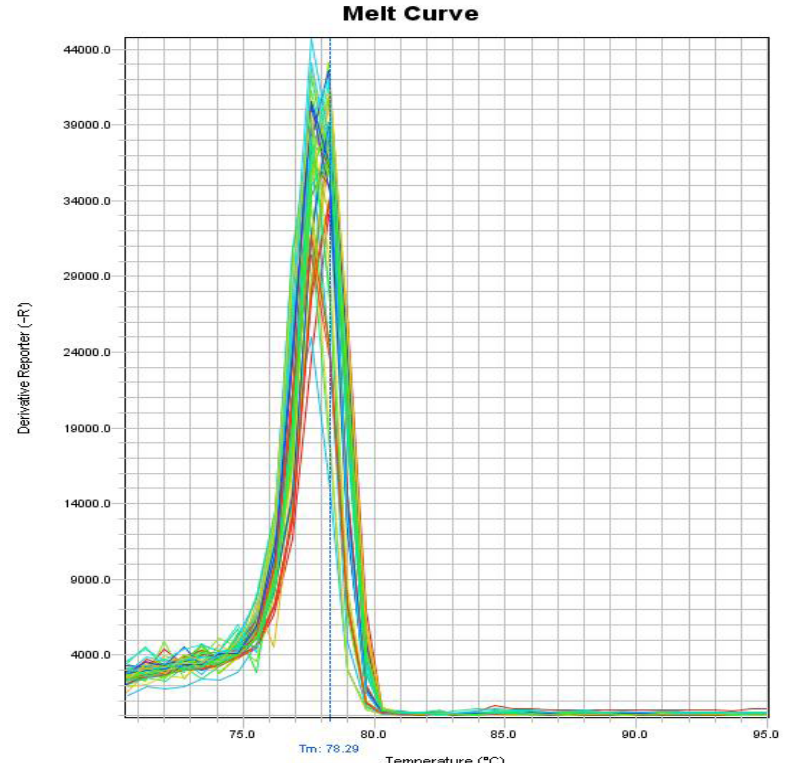

Figure 3. Melting curve of $18 \mathrm{~s}$ rRNA gene synthesized in vitro

stock of $100 \mu \mathrm{l}$ and then the required volumes of primers were added to $15 \mu \mathrm{L}$ of PCR reaction. There were $15 \mathrm{ng}$ samples in each $\mu \mathrm{L}$ of DNA. After a spin of 5 seconds, we finally transferred the strips to the Real-time PCR device to operate under the determined settings. In this method, a DNA sample with a specific concentration was used to draw a standard curve. The standard DNA concentration was determined with a $260-\mathrm{nm}$ spectrophotometer and then converted to the number of copies based on the molecular weight of the sample. The 18s rRNA gene was sequenced and then sent to Takapouzist company for synthesis. After synthesis, serial dilution was prepared from the standard samples and placed in real-time PCR device with the target sample. Using the $\mathrm{Ct}$ (Threshold Cycle) value for each dilution, we drawed a curve in which $\mathrm{X}$ axis showed the dilution or the number of copies of the gene and $\mathrm{Y}$ represented the expected $\mathrm{Ct}$ value. The length of the gene sequence was $234 \mathrm{bp}$. When the lyophilized state was liquefied by adding $100 \mu 1$ of injected distilled water, its concentration was measured with a nanodrop.

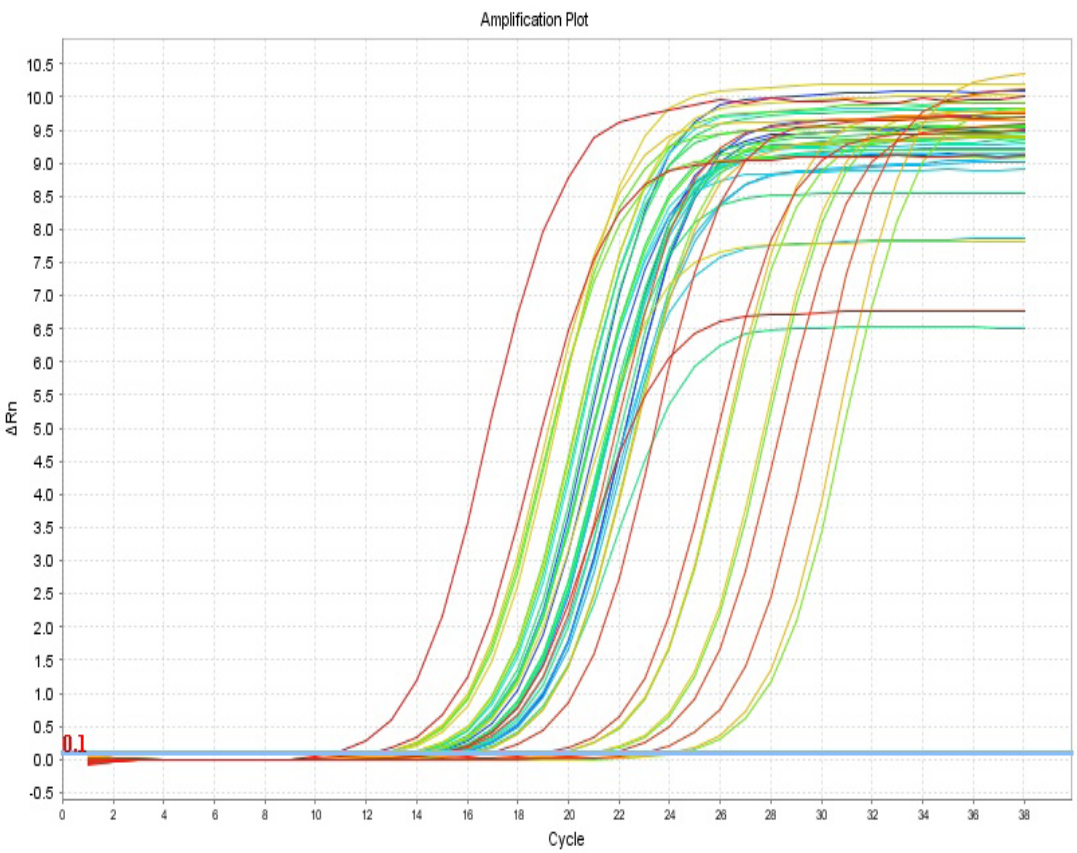

Figure 4. Amplification curve of $18 \mathrm{~s}$ rRNA gene synthesized for IC50 testing in vitro 


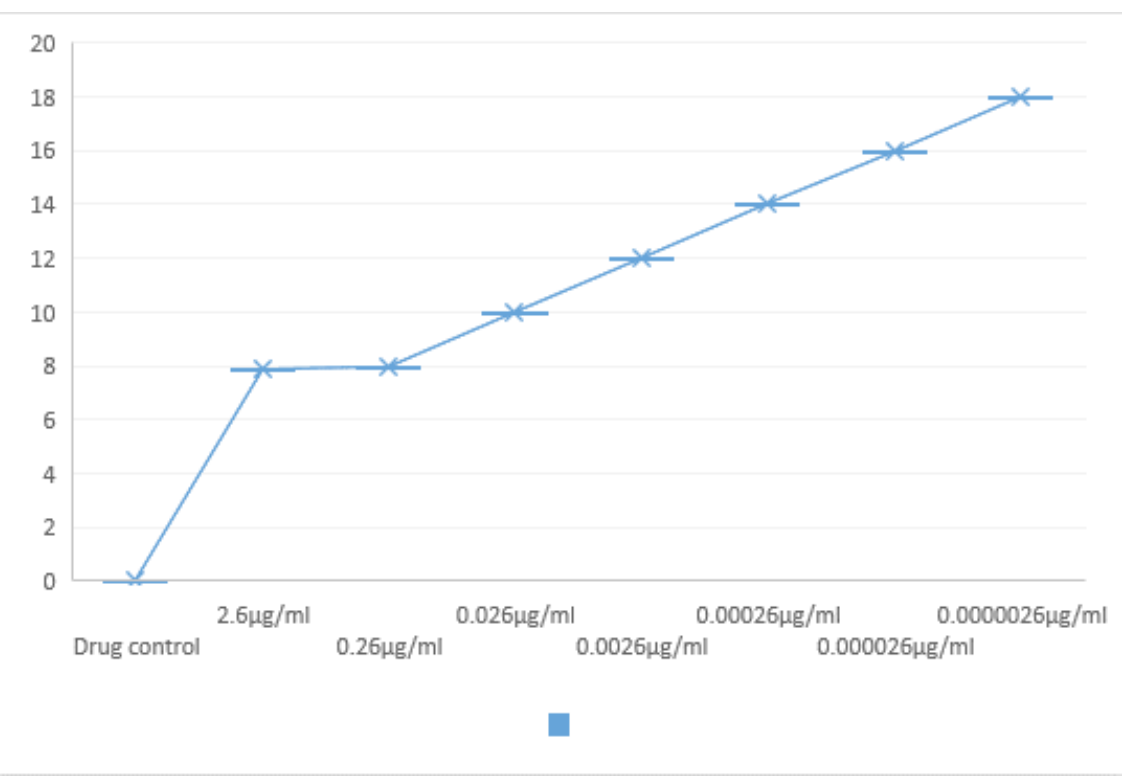
Figure 5. Determination of IC50 value of active fractions obtained from ion exchange chromatography using Real-time PCR method

\section{Results}

For quantitative analysis of gene expression, information obtained from $18 \mathrm{~s}$ rRNA gene expression was synthesized and cloned with the results of the standard curve of $18 \mathrm{~s} \mathrm{rRNA}$ gene and normalized in PUC57. With the help of amplification diagrams, the CT value of the samples was determined, and the presence of non-specific products and primer dimers was determined with the help of melting curve. Figures 1, $2,3,4$, and 5 plot the standard, amplification, and melting curves of the $18 \mathrm{~s}$ rRNA gene. They showed the specificity of real-time PCR conditions for this gene.

\section{Conclusion}

The obtained results showed that the anti-Plasmodium effect of the active fraction of snake venom is quite apparent. These promising results motivate further research in this area; Therefore, according to the obtained results, it will not be far-fetched to develop new effective antimalarial drugs after systematic research in this field.

\section{Ethical Considerations}

Compliance with ethical guidelines

This research observed the ethical principles according to Declaration of Helsinki, and obtained its ethical approval from Iran University of Medical Sciences (Code: IR.IUMS. REC1395.9223651202).

\section{Funding}

This research was supported by the research project (No. IR.IUMS.REC1395.9223651202), Funded by the Iran University of Medical Sciences.

Authors' contributions

All authors contributed equally in preparing this article.

Conflicts of interest

The authors declare no conflict of interest.

Acknowledgements

The authors would like to thank the Iran University of Medical Sciences and Pasteur Institute of Iran for funding and cooperation in conducting specialized tests. 
This Page Intentionally Left Blank 


\section{Real-time PCR بررسى اثر ضد باسموديومى سم مار كبراى ايراثى با روش مولكولى}

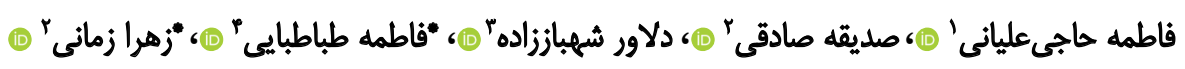

1. كروه انكل شئاسى و قارجشناسى، دانشكده يزشكى، يرديس بين الملل دانشكاه علوميزشكى ايران، تهران، ايران.

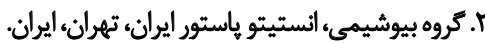

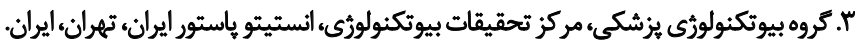

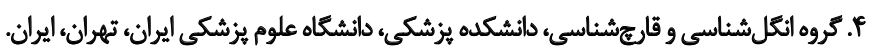

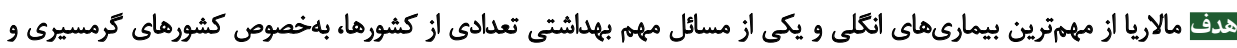

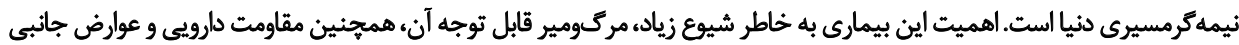

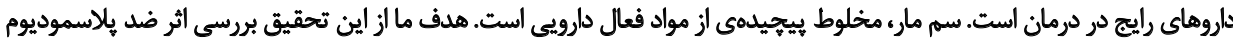

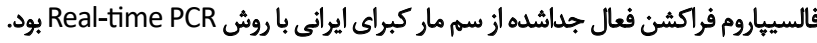

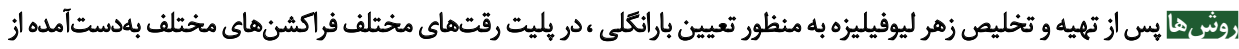

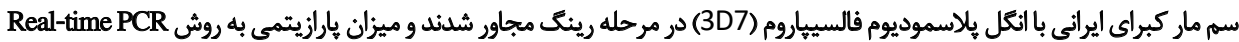

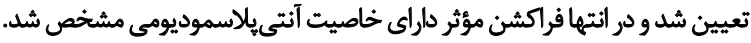
يافته ها نتايج نشان داد كه فراكشن فعال با غلظت

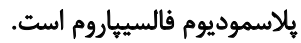

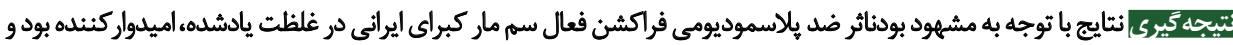

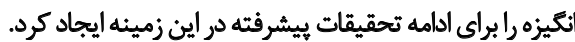

اطلاعات مقاله:

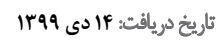

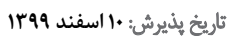

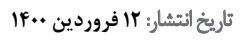

كليدوأوهها: يلاسموديوم فالسيياروم، غلظت مهار ميائهء سهري ماروم مار، مالاريا، واكنش هائى زنجيرهاي بليمراز

شدت تحليل مىبرد و باعث كاهش شديد فعاليت هايبيمار در

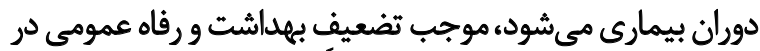

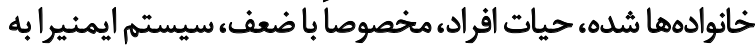

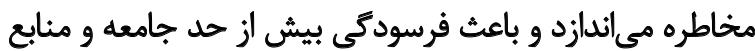

$$
\text { انسانى كشورها مي شود. }
$$

مالاريا از مههمترين بيمارىهاى انكلى است كه توسط

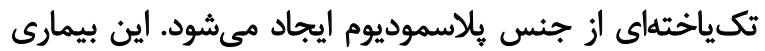

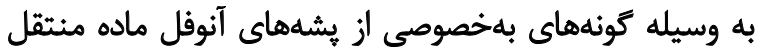
به دليل سهولت مسافرت و تبادل جمعيتى بامناطق مالارياخيزء

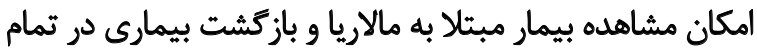

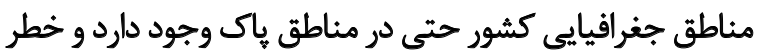

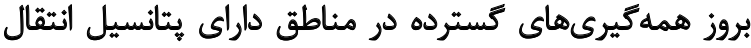

$$
\text { همواره مطرح است [1، [1]. }
$$

به دليل برنامه حذف مالاريا در جهان و استفاده از درمان

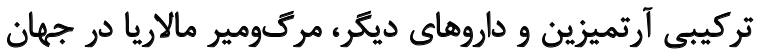

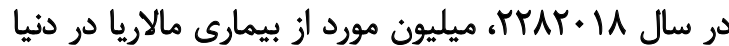

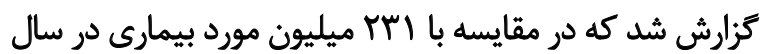

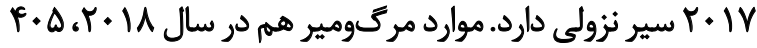

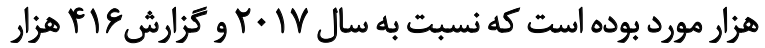
مورد سير نزولى داشته است.

اين بيمارى علاوه بر اينكه طي حملات خود نيروى بيمار رابه
دكتر زمرازمائى - مئي

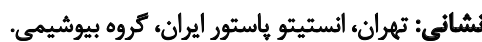

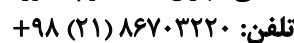
بست الكترونيكى:tabatabaie59@gmail.com
"نويسنده مسئول:

دكتر فاطمه طباطبايى

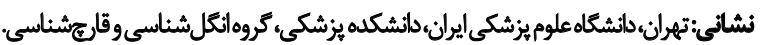

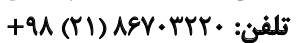
tabatabaie59@gmail.com:بست الكترونيكى. 
مواد و روشها

تعيين رُز موثر فراكشن فعال مرحله دوم يا ( ICOA) با روش

Real-time PCR

براى انجام اين مطالعه تجربى ابتدازهر ليوفيليزه رااز در انستيتو

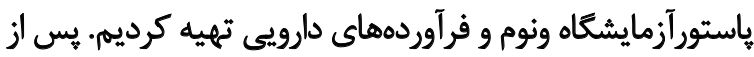

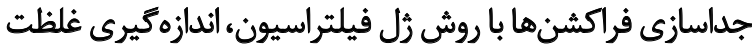

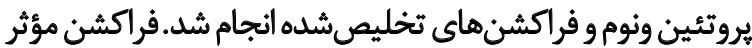

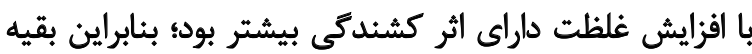

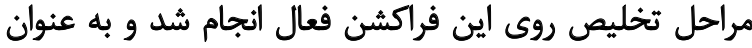

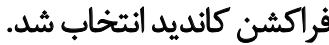

در مرحله بعد، كشت انكل يلاسموديوم فالسيخاروم را انجام داديم.

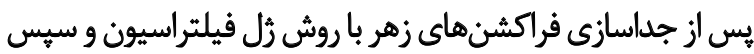

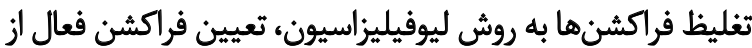

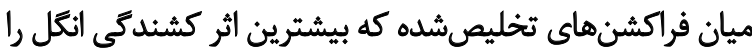

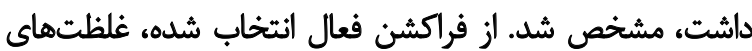

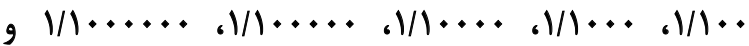
(1/......

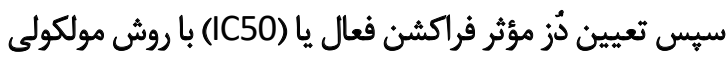
دقيق انجام شد. روش مولكولى

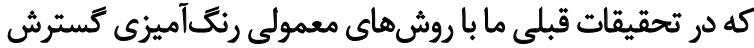

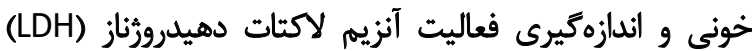

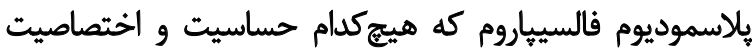
روشهاى مولكولى را ندارند، انجام شده بود [1T]

\section{DNA استشخراج}

براى بررسى سطح بيان ثنهاى 18s rRNA يلاسموديوم

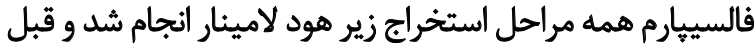

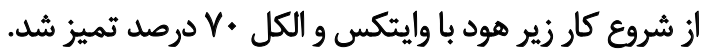
وسايل كار براى استخراج شامل سميلرها، سرسميلرها و و

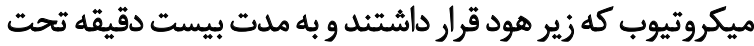

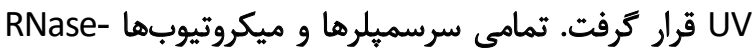

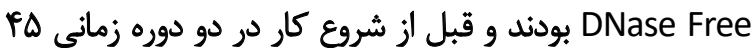

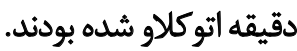

ابتدا عانصد ميكروليتر خون در فالكون يانزده ريخته با بآب دو

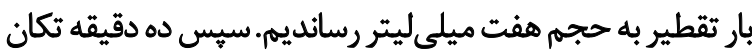

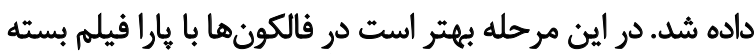

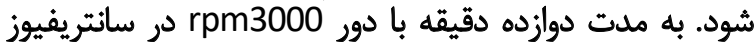
يخجال دار،سانتريفيور شد.

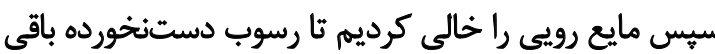

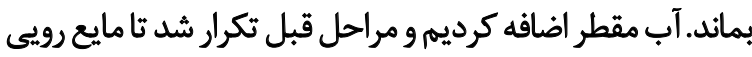

يايين آمده است، ولى متأسفانه در نقاط مختلف جهان فراوانى

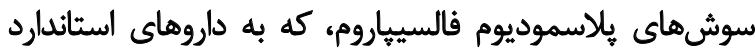
مانيد كلروكين مقاوم هستند، افزايش يافته است.

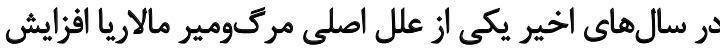

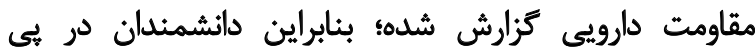
جستوجوى دارويى جديد جهت مهار كردن اين بيمارئ دارئ هستيند

[I. Y]

با بيشرفت علم يزشكى و علوم وابسته، در سالهاى اخير

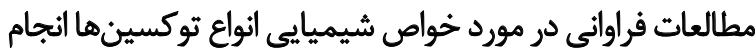

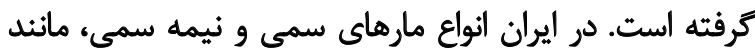

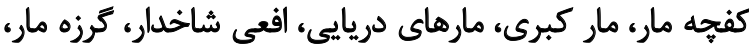
افعى دماوندى، افعى البرز و مار جعفرى زيست مارئ مي كنيند. مار كبراى ايران (Naja Naja Oxiana) از مارهاى خانواده

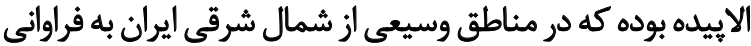

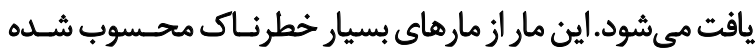

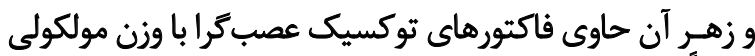
نسبتاً يايين است.

امروزه از بزاق يا به عبارتى همان زهرمارها مي توان انواع داروهاء

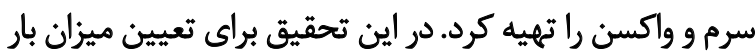

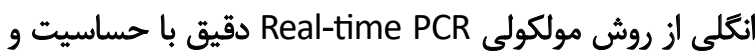
اختصاصيت بالا استفاده كرديم كه تأييدكنينده نهايى روشين إنهاى

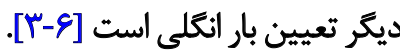

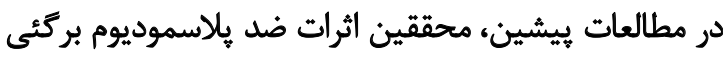

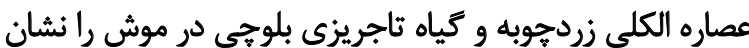

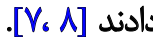

مطالعات سال هاى كذشته نشان داده كه ائوزين B به عنوان

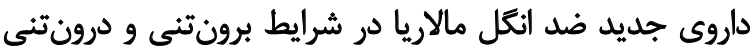

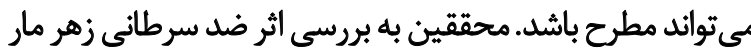

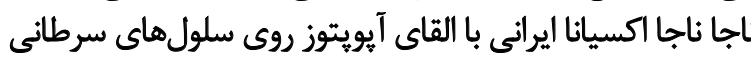

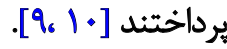

در سالهاى كذشته محققين با افزايش موارد مقاومت

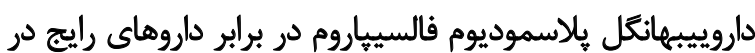

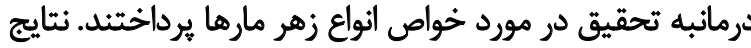

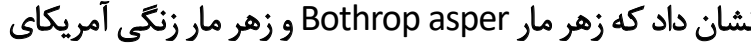

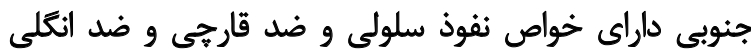

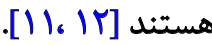

هدف ما از اين تحقيق، بررسى اثر ضد يلاسموديوم فالسيياروم

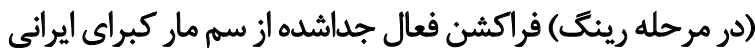

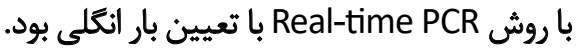


Injection Water

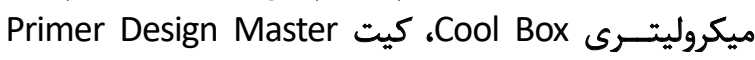
SYBR ديكتاه SYBI Step One، دريوش آنها. Real-time PCR ووش أنجام آزّمايش

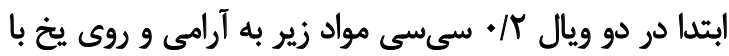

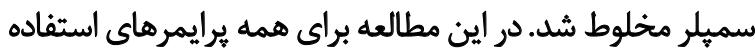

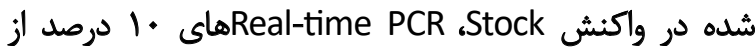

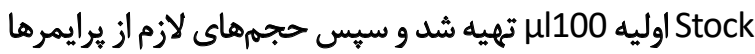

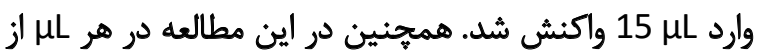

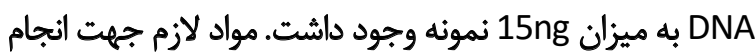
Real-time PCR يس از يك Spin ينج ثانيهاى درنهايت استريبها را به دستَاه Real-time PCR

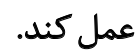
در اين روش از نمونه DNA با غلظت مشخص براى رسم

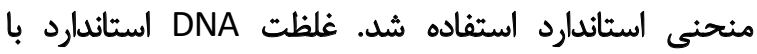

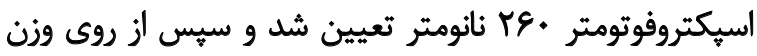

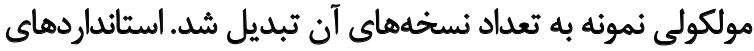
غلظتى ثنهاى معروف به صورت تجارى قابل خريدارى است.

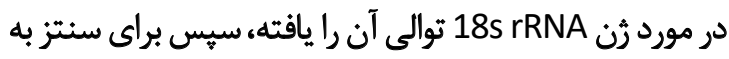

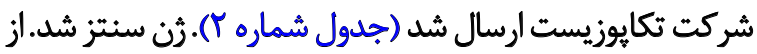

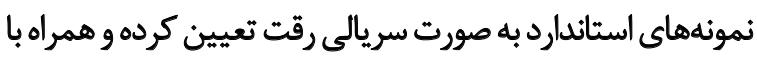

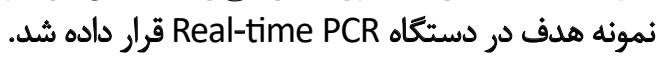

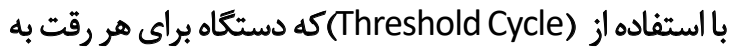

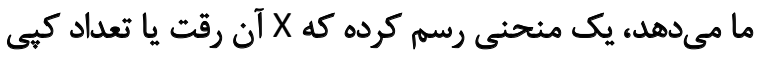

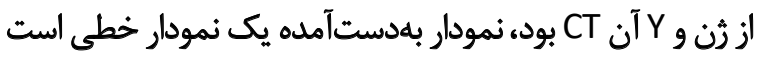

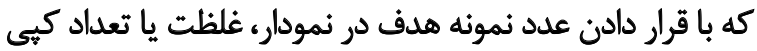

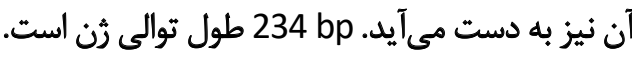

AACACGGGGAAACTCACTAGTTTAAGACAAGAGTAGGATTGACAGATTAATAGCTCTTTCTTGATTTCTTGGATGaGTGATGCATGGCCGTTTTTAGTTCGTGAATATGATTTGTCTGGTTAATTCCGATAACGAACGAGATCTTAACCTGCTAATTAGCGGTAAATACACTATATTCTTAAGTGAAATTAGAATATAGATAAATTGTGCTAATTTTGATTAAAATATTAGAATG

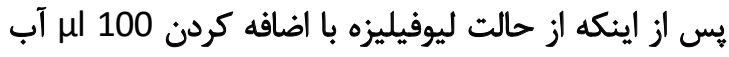

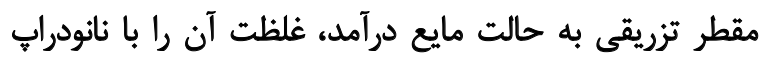

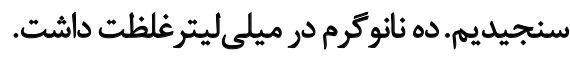

فرمول تبديل غلظت به تعداد نسخههاى ثن:

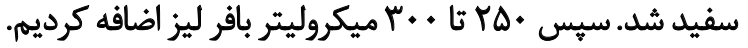

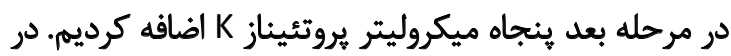

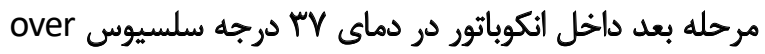

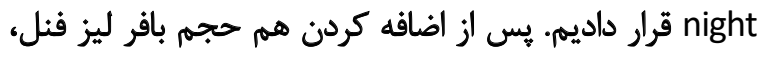

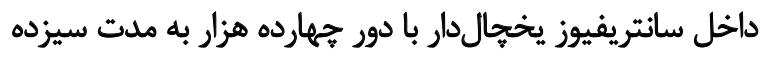

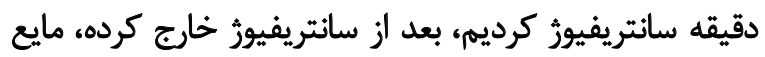

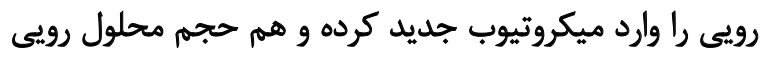

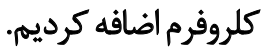

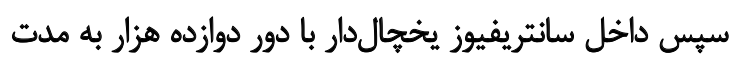

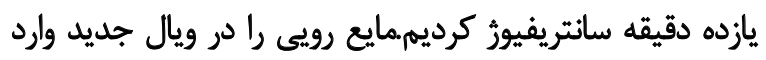

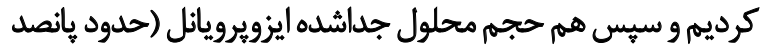

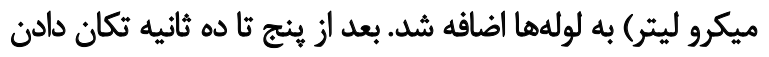

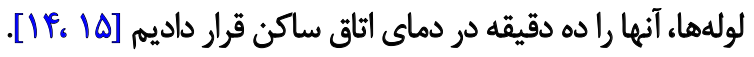

\section{DNA Dشتوشوى}

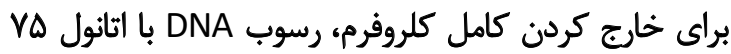

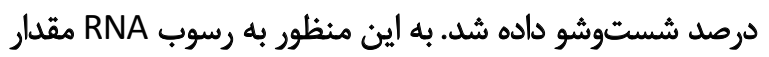

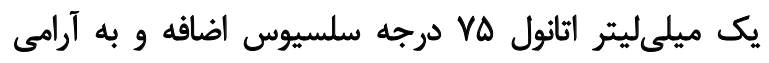

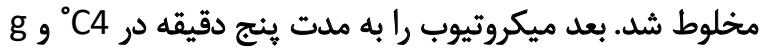

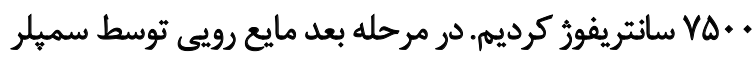
دور ريخته شئ. Dشك كردن رسوب DNA براى خشك شدن نسبى رسوب ده دقيقه درِ ميكروتيوب باز

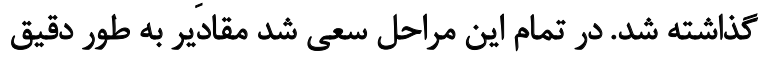

$$
\text { و صحيح رعايت شوند. }
$$

رن 18s rRNA در يلاسموديوم داراى كيى نامبر بالايى است.

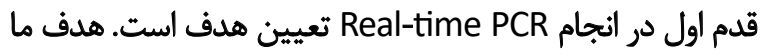

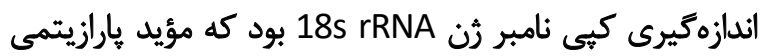

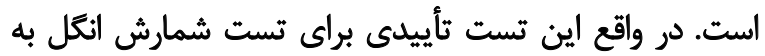

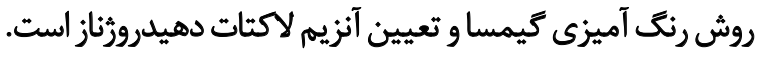

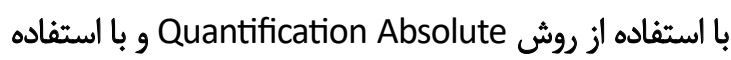
از يك منحنى استاندارد تعداد دقيق نسخههاي 18s rRNA كلون استفاده

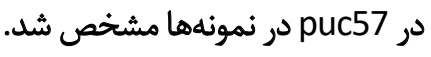

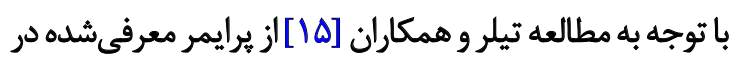

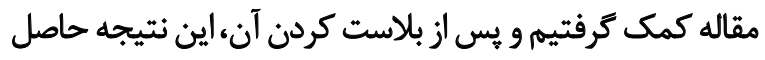

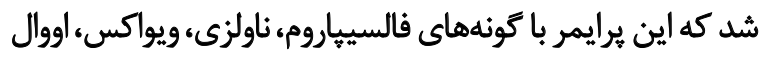

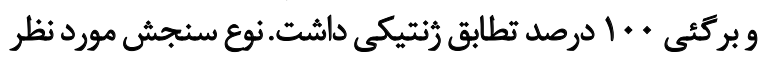

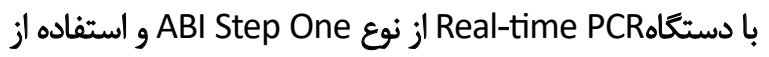
روش با دستSY بود. Real-time PCR مواد لازم براى انجام 
جدول ا. مواد لازم براى

\begin{tabular}{|c|c|}
\hline 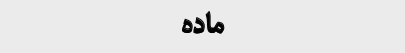 & حجم - 1 - 1 \\
\hline SYBER Green (primer design) & $7.5 \mu \mathrm{L}$ \\
\hline $\mathrm{ddH} 2 \mathrm{O}$ & $5.5 \mu \mathrm{L}$ \\
\hline Forward Primer & $0.5 \mu \mathrm{L}$ \\
\hline Reverse Primer & $0.5 \mu \mathrm{L}$ \\
\hline sample & $1 \mu \mathrm{L}$ \\
\hline $15 \mu \mathrm{L}$ & Total \\
\hline
\end{tabular}

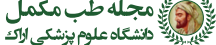

تست تعيين بار انكلى روى فراكشنهاى جداشده در مرحله

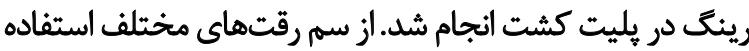

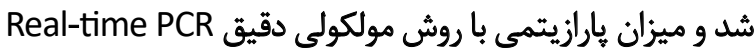

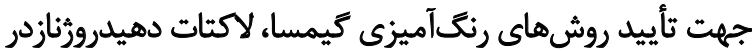

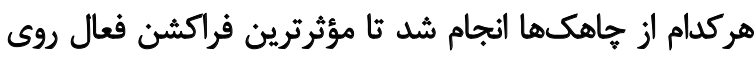
انكل بلاسموديوم فالسيهاروم تعيين شود.

تعيين دُز مؤثر فراكثن فعال مرحله دوم يا ( • (ICD) با روش Real-time PCR

در تصويرهاى زير مى ثوان منحنى تكثير و ذوب مربوط به ثن ين Sيتي 18s rRNA

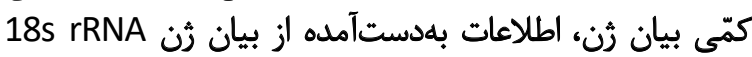

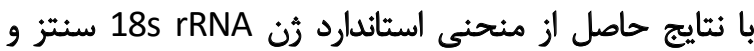
كلونشده ودر PUC57 نـرمـال سازي شدان.

با كمك نمودارهاى تكثير ميزان CT(Threshold Cycle) نمونهها مشخص شد و به كمك منحنى ذوب دوب (Melt curve)

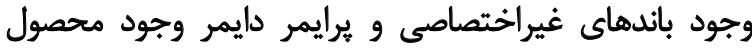

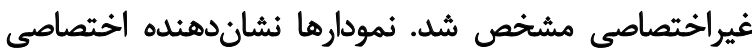
بودن شرايط انجام Real-time PCR براي اين ثرامن است. منحنى استاندارد رن دان 18srRNA سنتزشده و كلونشده در

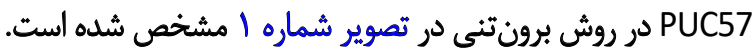

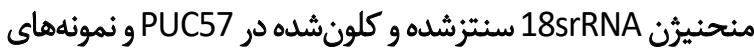

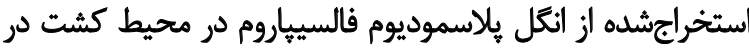
مجاورت فراكشن فعال جهت تست IC50 در روش برونتنى در درد number ofcopies (moleules) $=$

$\frac{X n g^{*} 6.0221 \times 10^{23} \text { moleules } / \mathrm{mole}}{\mathrm{N}^{*} 660 \mathrm{~g} / \mathrm{mole}^{*} * 1 \times 10^{9} \mathrm{ng} / \mathrm{g}}$

غلظت ده نانوگرم X = amount of amplicon (ng)

جفت باز MrF N = length of dsDNA amplicon

$660 \mathrm{~g} / \mathrm{mole}=$ average mass of $1 \mathrm{bp}$ dsDNA

در هر نانوكرم صد هزار نسخه رن وجود داشت، ابتدا رقت

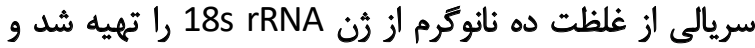

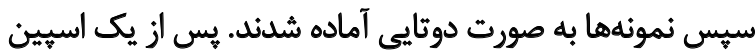

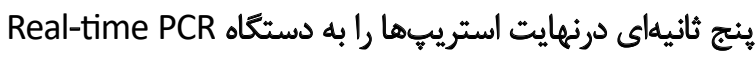
انتقال داديم ثاتحت برنامه دادهشده به دستخاه عمل كند. شرايط سيكل دمايي Real-time PCR براى رُّنهدف به قرار زيو بود

يك مرحله C95" براى جهارده دقيقه جهت فعال سازى آغازى

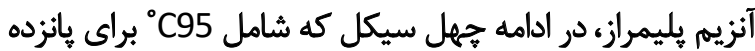

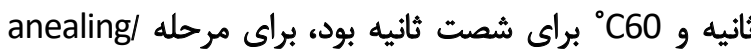
extention (Melt Curve Analysis) م براي يانزده ثانيه،

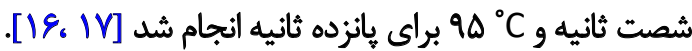

\section{يافتهها}

جدول r. برايمرهاي مورد استفاده براى RCP emti-laeR

\section{Primers}

\section{Reverse Primer}

Forward Primer

\section{Primer pair sequences}

5'-GCTCTITCTTGATTTCTTGGATG - 3

5' - AGCAGGTTAAGTTCTCGTTCG-3'

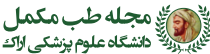




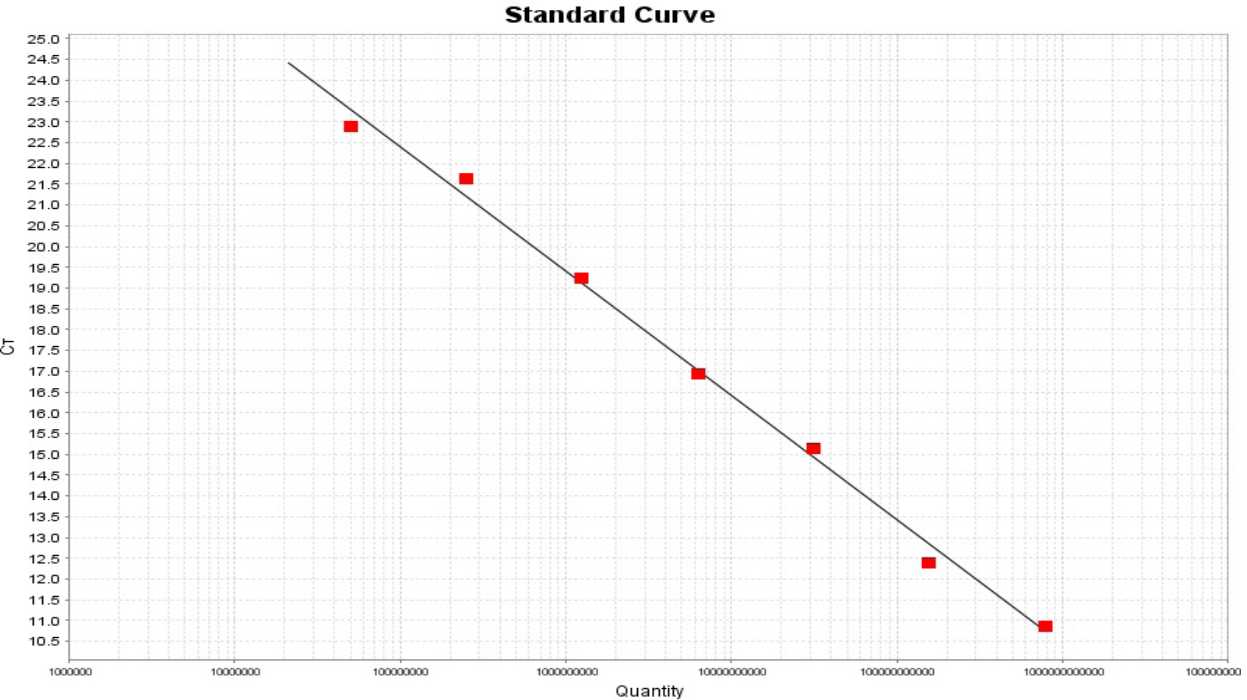

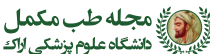

انكل بلاسموديوم، عامل مولد مالاريا تأثير بسيار كستردهاي

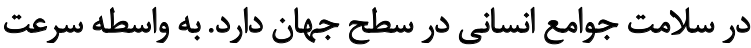

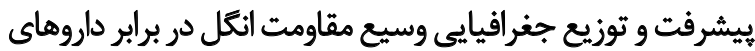

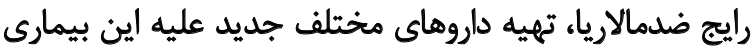
يك ضرورت قطعى است. ظهور مقاومت دارويى به معناى افزايش خطر عوارض جانبى و يا مخارج بيشتر در استفاده از داروهاي جديد است [r]

انتل هلاسموديوم در مرحله رينگ داراى فعاليت مثابوليك بالايى است. به اين دليل از مرحله رينغ انكل استفاده كرديم
تصوير ا. منحنى استاندارد رن 18s rRNA سنتزشده در روش برونتنى تصوير شماره Y نشان داده شده است. در تصوير شماره ب منحنى

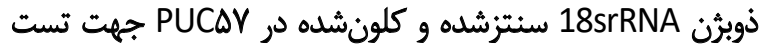

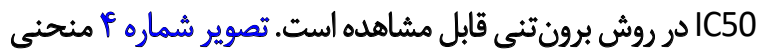

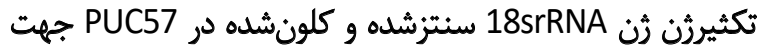
تست IC50 در روش برونتنى را مشخص مى كن كند. در تصوير شماره

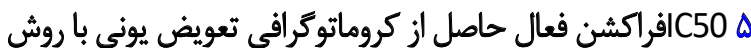
Real-time PCR

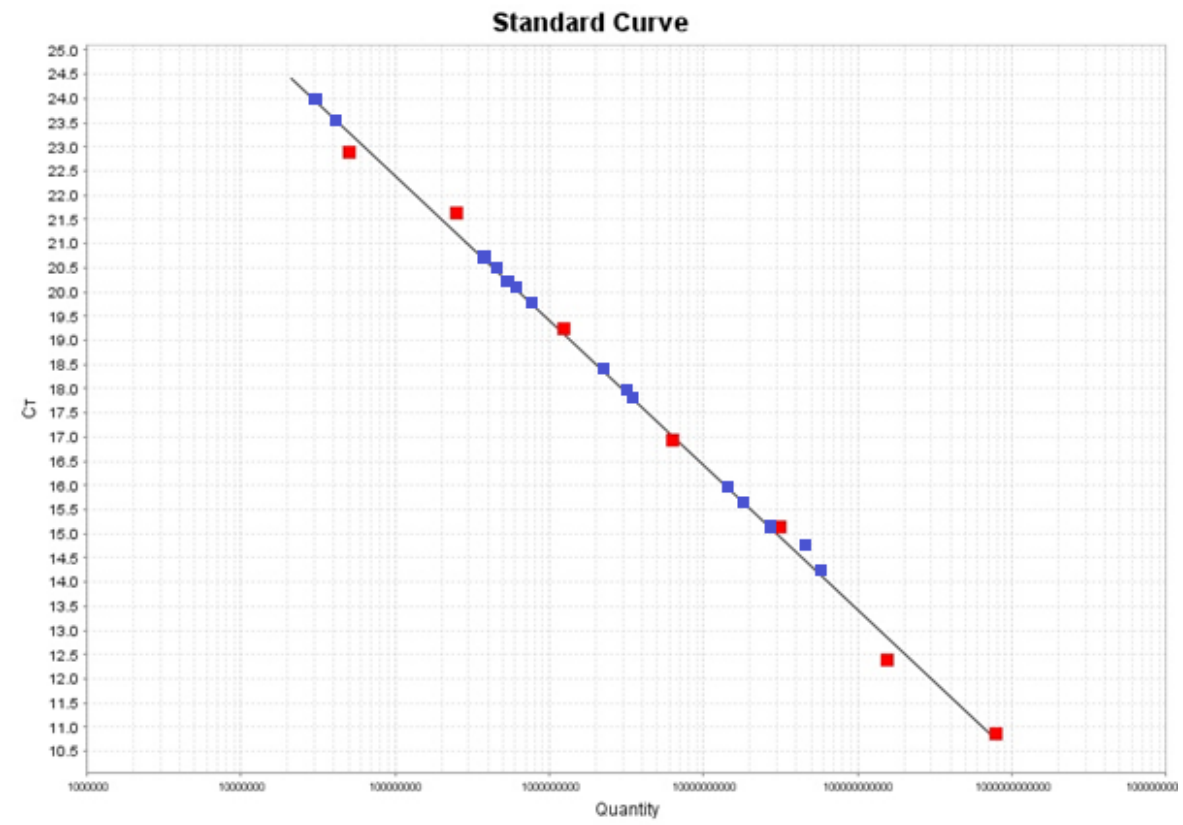

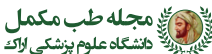

تصوير r. منحنى ثن 18s rRNA سنتزشده و نمونهماى استخراجشده از انكل بلاسموديوم فالسيياروم در محيط كشت در مجاورت فراكشن فعال جهت تست lC50 


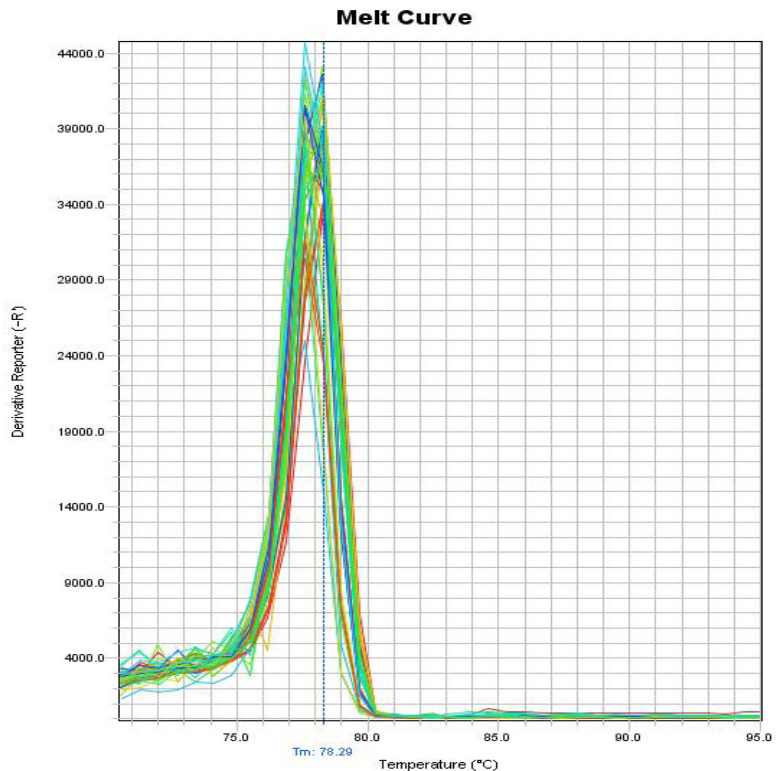

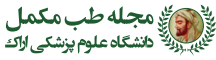

تصوير ب. منحنى ذوب ثن 18s rRNA سنتز شده به روش برونتنى كه در الدامه تحقيقات به بررسى يروفايل متابوليتهاى انكل در آمينها است. مههمترين آنزيمهها شامل فسفوليياز AY، آمينو اسيد اكسيدازء

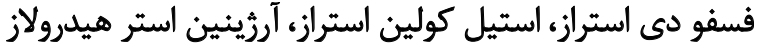

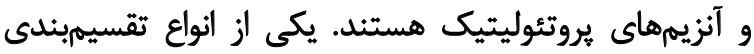

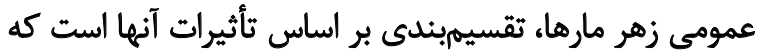

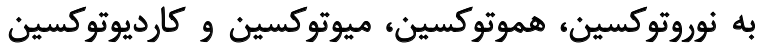

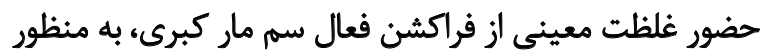

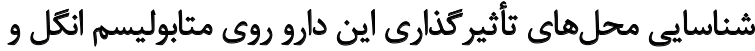

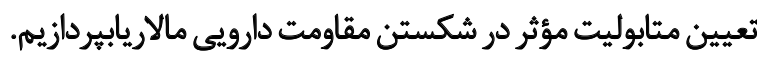

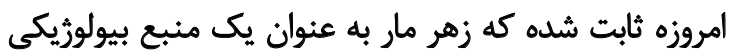

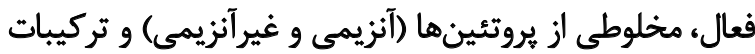
غيربروتئينى ازقبيل فلزات، جربى إنها، نوكلئوتيدها، كربوهيدراتهاتيات تركيات

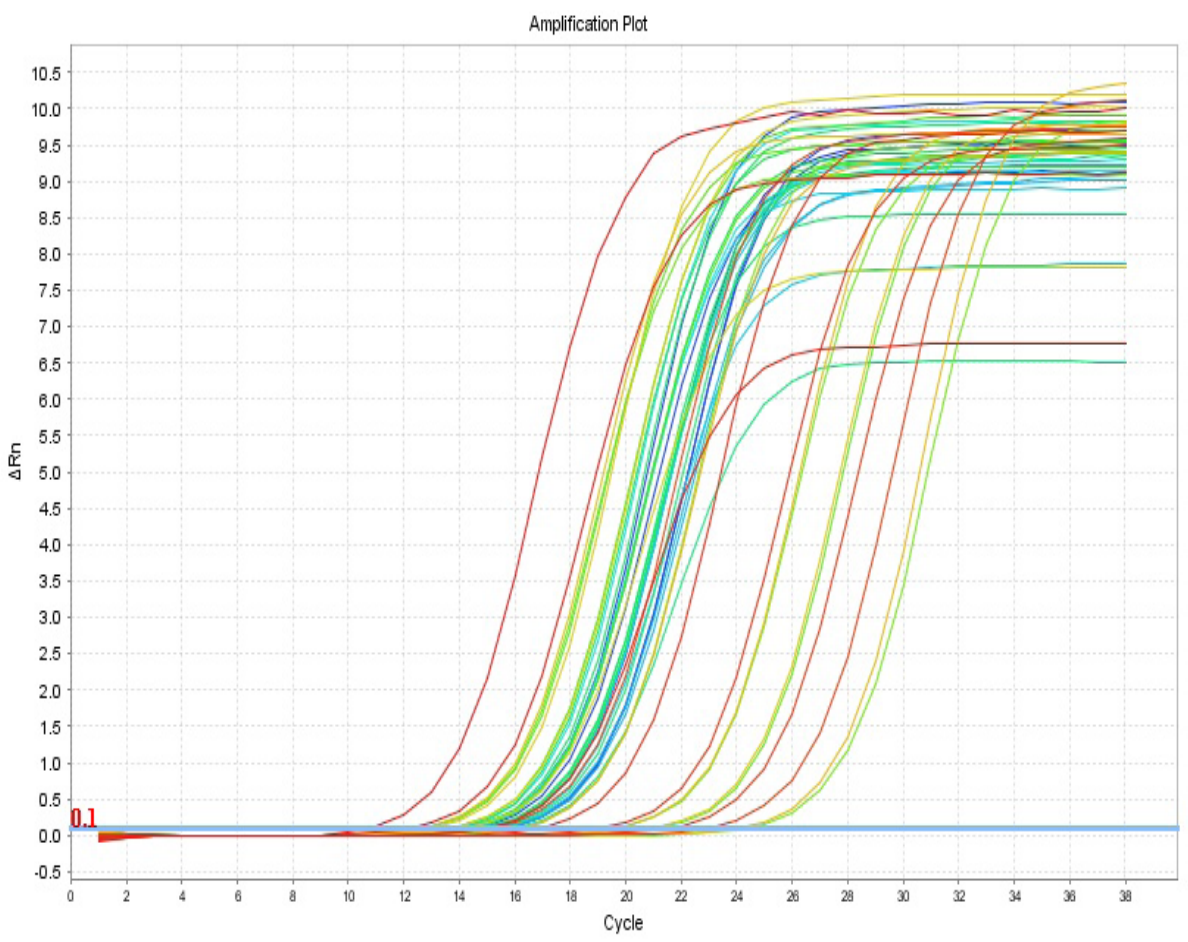




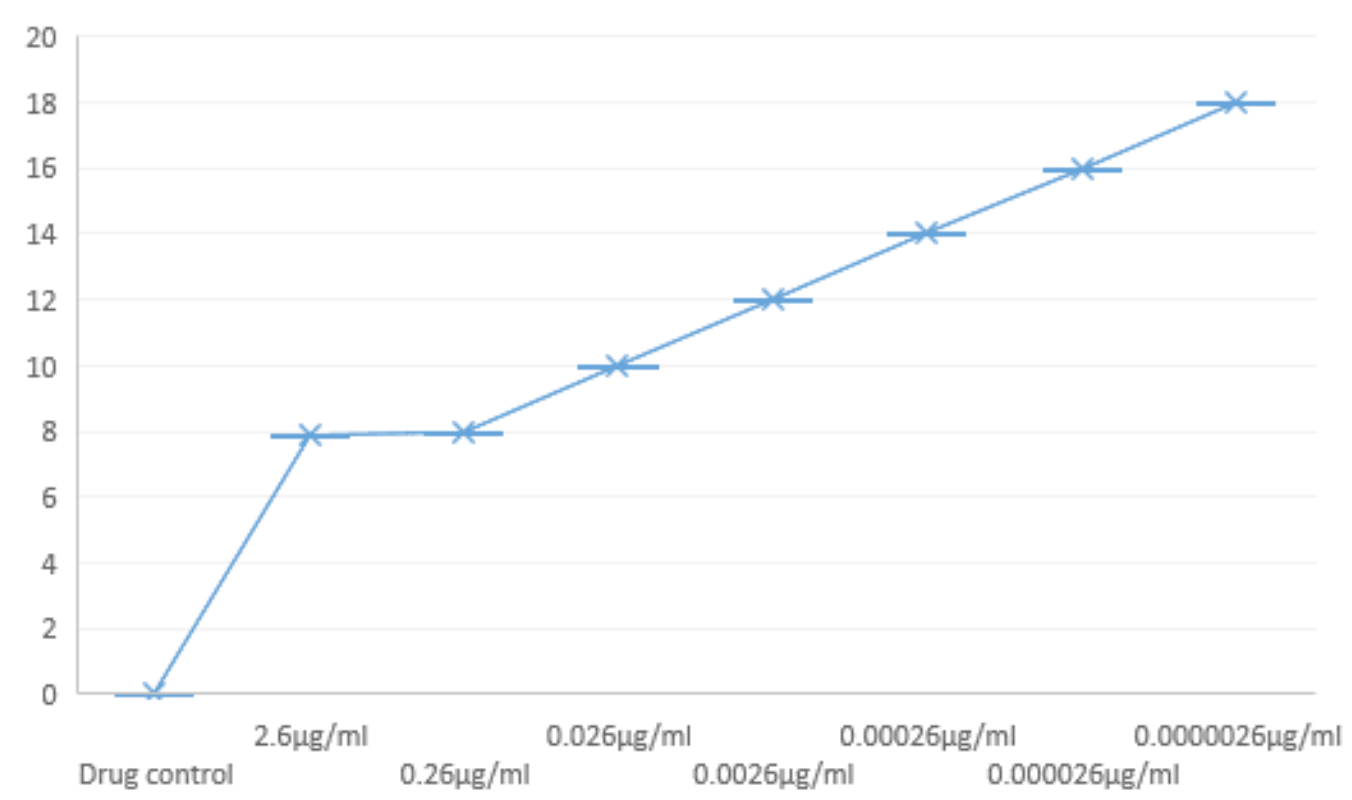

|

Real-time PCR تصوير هـ تعيين اقراكشن فعال حاصل از كروماتوكرافي تعويض يونى با روش

جنس، كونه و تحت كُونه ميكرواركانيسمها همجنين تعيين مقاومت دارويى اشاره كرد.

منكولد و همكاران براى افتراق كونههاى يلاسموديوم در

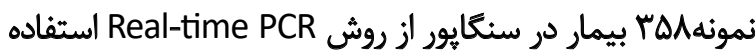

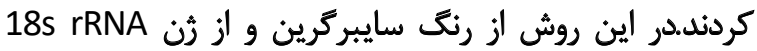

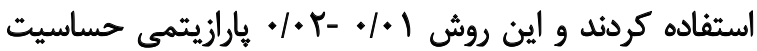

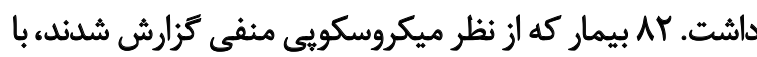

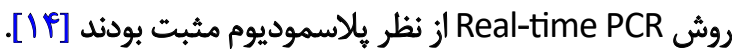

تيلر و همكاران با استفاده از روش Deal-time PCR DNA

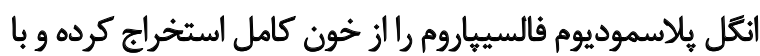
استفاده از رنك سايبركرين و استفاده از رثن 18s rRNA به تعيين يارازيتمى يرداختند واين روش استخراج DNAانكل يلاسموديوم

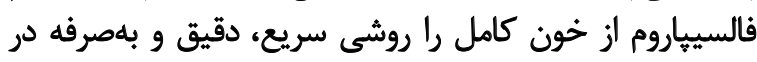

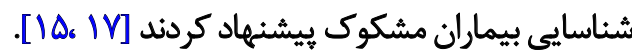

وجود يك آزمون اختصاصى و حساس براى تشخيص اين انكل

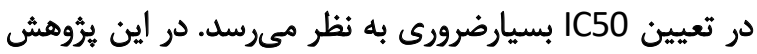

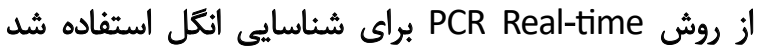
كه روشى حساس و اختصاصى است. رن روش

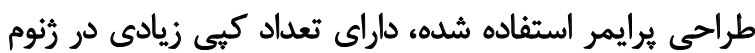
انغكل است.

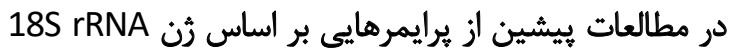

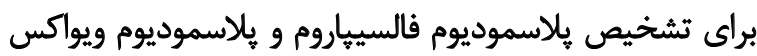

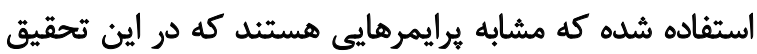

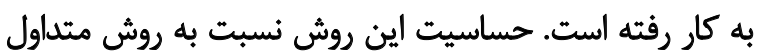

جيلانوم و همكاران نشان دادند كه كاهش فسفوليبيد در

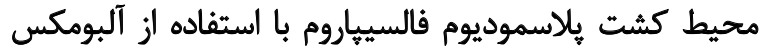

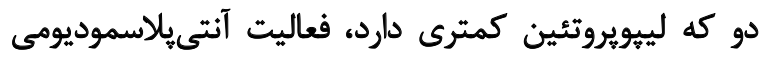

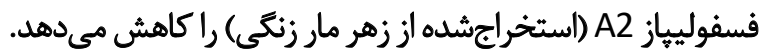

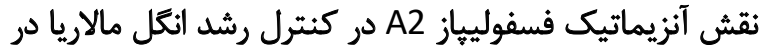

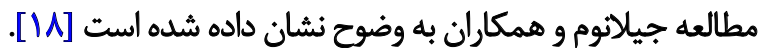

كاستيلو و همكاران به بررسى فعاليت آنزيم فسفوليياز A2 و

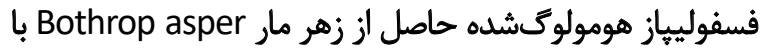

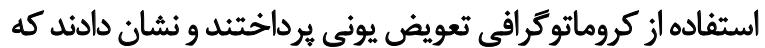

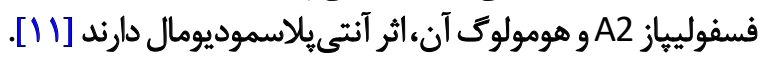

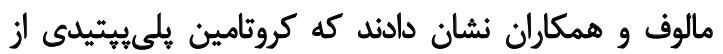

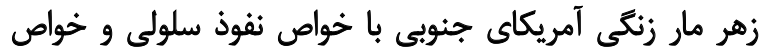

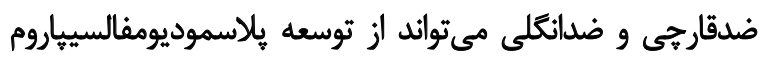

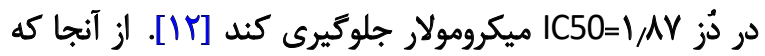
شناسايي دقيق و سريع عوامل عفوني از مطالبات مهرم جامعيد

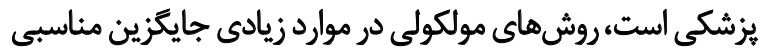

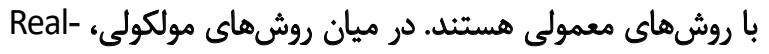
time PCR(qPCR) عفونتزا يافته است، اين روش كه بر مبناى شناسايى و تكثير رثنوم

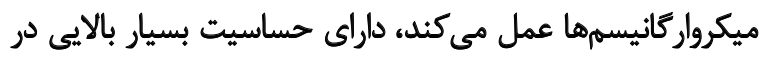

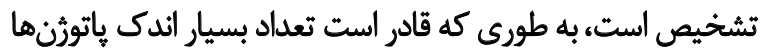
راكه با روشهاى ديگر قابل شناسايى نيستند، تشخيص دهد.

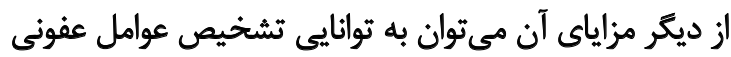

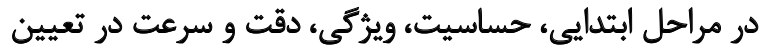




$$
\text { تشكر و قدردانى }
$$

نويسندكان اين مقاله از دانشكاه علوم يزشكى ايران و انستيتو

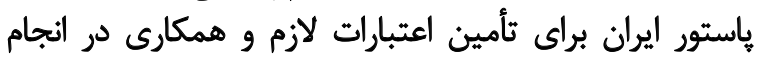
آزمايشات تخصصى برورثه تشكر و قدرداني مي كنيند.

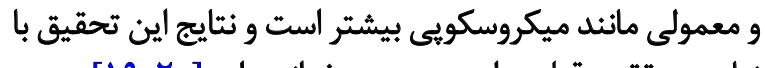

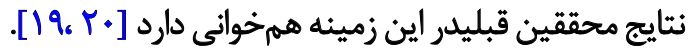

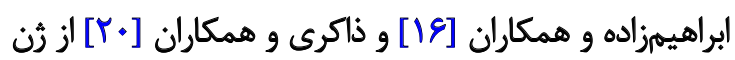

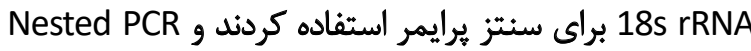

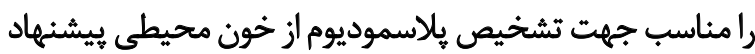

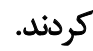

علاوه بر ثأمين بودجه جهت خريد كيت و زمان رسيدن

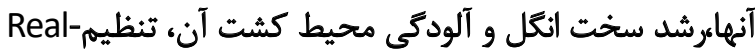
time PCR از مهمترين محدوديتها و مشكلات تحقيق نام برد.

$$
\text { تبيجهيرى }
$$

تعيين بار انتلى با روش مولكولى qPCR تأييدكنيده قطعى رئي

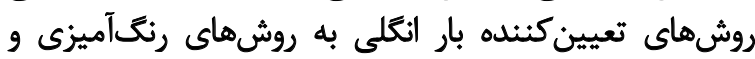

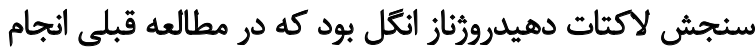
شلهه يود.

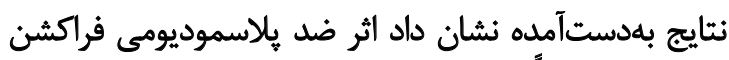

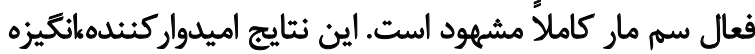

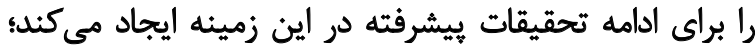

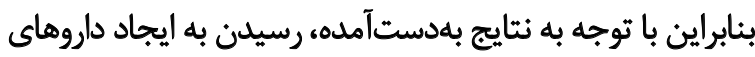

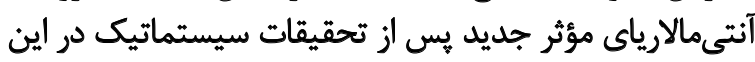

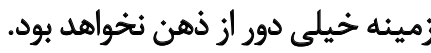

\section{مالاحظات اخلاقي - ماتي}

\section{ي ميروى از اصول اخلاق يثوهش}

كميته اخلاق دانشكاه علوم بزشكى ايران اين مقاله را ثأييد كرده است (كد اخلاق: كميته اخلاق داه علوم يزشكى ايران اين مقاله رأيديد

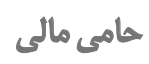

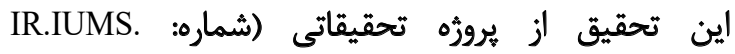

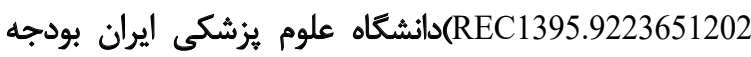

$$
\text { دريافت كرده است. }
$$

تمام نويسندكان در طراحى، اجرا و نتارش همه بخشهاى يُورهش حاضر مشاركت داشتهاند.

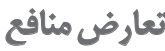

بنابر اظهار نويسندكان اين مقاله تعارض منافع ندارد. 


\section{Refrences}

[1] Chirebvu E, Chimbari MJ, Ngwenya BN. Assessment of risk factors associated with malaria transmission in tubu village, northern botswana.Malaria Research and Treatment. 2014; 2014:403069. [DOI:10.1155/2014/403069] [PMID] [PMCID]

[2] Sant'Ana CD, Ticli FK, Oliveira LL, Giglio JR, Rechia CG, Fuly AL, et al. BjussuSP-I: A new thrombin-like enzyme isolated from Bothrops jararacussu snake venom. Comparative Biochemistry and Physiology Part A: Molecular \& Integrative Physiology. 2008; 151(3):443-54. [DOI:10.1016/j.cbpa.2007.02.036] [PMID]

[3] Utkin YN. Animal venom studies: Current benefits and future developments. World Journal of Biological Chemistry. 2015; 6(2):28-33. [DOI:10.4331/wjbc.v6.i2.28] [PMID] [PMCID]

[4] Liu CC, Yang H, Zhang LL, Zhang Q, Chen B, Wang Y. Biotoxins for cancer therapy. Asian Pacific Journal of Cancer Prevention 2014; 15(12):4753-8. [DOI:10.7314/APJCP.2014.15.12.4753] [PMID]

[5] Dhananjaya BL, Sivashankari PR. Snake venom derived molecules in tumor angiogenesis and its application in cancer therapy; An overview. Current Topics in Medicinal Chemistry. 2015; 15(7):649-57. [D OI:10.2174/1568026615666150225113402] [PMID]

[6] Malleswari M, Josthna P, Doss PJ. Orally Administered Venom of Naja Naja Alters Protein Metabolic Profiles in the Liver of Albino Rats. International Journal Of Life Sciences Biotechnology And Pharma Research. 2015; 4(1):10-6. https://citeseerx.ist.psu.edu/viewdoc/ download?doi=10.1.1.676.7515\&rep=rep1\&type=pdf

[7] Heydarian P, Nateghpour M, Mazhari N, Motevalli Haghi A, Farivar L, Souri E, et al. Evaluation of Effectiveness of Ethanolic Extract of Curcuma longa, discretely and in Combination with Chloroquine against Chloroquine-Sensitive Strain of Plasmodium berghei. Herbal Medicines Journal. 2018; 3(4):133-8. http://eprints.lums.ac.ir/id/ eprint/1961

[8] Garedaghi Y, Khaki A. Evaluation of the effectiveness of ethanolic extract of solanum surattense against plasmodium berghei in comparison with chloroquine in sourian mice using in vivo tests. Crescent Journal of Medical and Biological Sciences. 2014; 1(3):76-9. http:// www.cjmb.org/text.php?id=113

[9] Massimine KM, McIntosh MT, Doan LT, Atreya CE, Gromer S, Sirawaraporn W, et al. Eosin $B$ as a novel antimalarial agent for drugresistant Plasmodium falciparum. Antimicrobial Agents and Chemotherapy. 2006; 50(9):3132-41. [DOI:10.1128/AAC.00621-06] [PMID] [PMCID]

[10] Ebrahim K, Vatanpour H, Zare A, Shirazi FH, Nakhjavani M. Anticancer activity a of Caspian Cobra (Naja naja oxiana) snake venom in human cancer cell lines via induction of apoptosis. Iranian Journal of Pharmaceutical Research. 2016; 15(Suppl):101-12. [PMID] [PMCID]

[11] Castillo JC, Vargas $\sqcup$, Segura C, Gutiérrez JM, Pérez JC. In vitro antiplasmodial activity of phospholipases A2 and a phospholipase homologue isolated from the venom of the snake Bothrops asper. Toxins. 2012; 4(12):1500-16. [DOI:10.3390/toxins4121500] [PMID] [PMCID]

[12] El Chamy Maluf S, Dal Mas C, Oliveira EB, Melo PM, Carmona AK, Gazarini ML, et al. Inhibition of malaria parasite Plasmodium falciparum development by crotamine, a cell penetrating peptide from the snake venom. Peptides. 2016; 78:11-6. [DOI:10.1016/j.peptides.2016.01.013] [PMID]

[13] Hajialiani F, Elmi T, Mohamadi M, Sadeghi S, Shahbazzadeh D, Ghaffarifar F, et al, Analysis of the active fraction of Iranian Naja naja oxiana snake venom on the metabolite profiles of the malaria parasite by 1 HNMR in vitro. Iranian Journal of Basic Medical Sciences. 2020 23(4):534-43. [DOI:10.1128/JCM.43.5.2435-2440.2005]

[14] Mangold KA, Manson RU, Koay ES, Stephens L, Regner M, Thomson RB Jr, et al. Real-time PCR for detection and identification of Plasmodium spp. Journal of Clinical Microbiology. 2005; 43(5):2435-40. [DOI:10.1128/JCM.43.5.2435-2440.2005] [PMID] [PMCID]

[15] Taylor BJ, Martin KA, Arango E, Agudelo OM, Maestre A, Yanow SK. Real-time PCR detection of Plasmodium directly from whole blood and filter paper samples. Malaria Journal. 2011; 10:244. [DOI:10.1186/1475-2875-10-244] [PMID] [PMCID]

[16] Ebrahimzadeh A, Fouladi B, Fazaeli A. High rate of detection of mixed infections of Plasmodium vivax and Plasmodium falciparum in South-East of Iran, using nested PCR. Parasitology International. 2007; 56(1):61-4. [DOI:10.1016/j.parint.2006.12.001] [PMID]

[17] Taylor SM, Juliano JJ, Trottman PA, Griffin JB, Landis SH, Kitsa P, et al. High-throughput pooling and Real-time PCR-based strategy for malaria detection. Journal of Clinical Microbiology. 2010; 48(2):5129. [DOI:10.1128/JCM.01800-09] [PMID] [PMCID]

[18] Guillaume C, Deregnaucourt C, Clavey V, Schrével J. Anti-Plasmodium properties of group IA, IB, IIA and III secreted phospholipases A2 are serum-dependent. Toxicon. 2004; 43(3):311-8. [DOI:10.1016/j. toxicon.2004.01.006] [PMID]

[19] Parvazi S, Sadeghi S, Azadi M, Mohammadi M, Arjmand M, Vahabi $F$, et al. The effect of aqueous extract of cinnamon on the metabolome of Plasmodium falciparum using 1HNMR spectroscopy. Journal of Tropical Medicine. 2016; 2016:3174841. [DOI:10.1155/2016/3174841] [PMID] [PMCID]

[20] Zakeri S, Mamaghani S, Mehrizi A, Shahsavari Z, Raeisi A, Arshi S, et al. Molecular evidence of mixed P. vivax and P. falciparum infections in northern Islamic Republic of Iran. Eastern Mediterranean health journal. 2004; 10(3):336-42. https://apps.who.int/iris/handle/10665/119418 